\title{
MIKÉNT JELENIK MEG A TANÁR MÁSIK SZAKJA A FÖLDRAJZ TANÍTÁSA KÖZBEN?
}

How does the second subject of the teacher manifest during teaching geography?

\author{
VARGA DÁVID CSABA \\ ELTE TTK FFI, IV. évfolyamos földrajz-biológia szakos egyetemi hallgató \\ v.davidcho99@gmail.com
}

\begin{abstract}
Geography as a subject in the school has a special role among the subjects, because partly natural, partly human science. It gives the teachers opportunity to modify the emphases of the subject towards either of them. The ranks of importance and preferences are considerably turning on the fact, what kind of other subject is (or subjects are) still taught by the geography teachers.
\end{abstract}

Keywords: subject integration, synthesizing approach, geography teaching, national curriculum, rank of importance, rank of preferences

\section{BEVEZETÉS}

W. D. Pattison szerint a földrajz olyan a tudományok között, mint egy metropolisz Amerikában: hatalmas területre terjed, összeolvad, kapcsolatot teremt szomszédaival és kifejezetten nehéz megtalálni a központját. Ez a mottó véleményem szerint teljes mértékben tükrözi a földrajz speciális helyzetét a természettudományok között. „A földrajz egyidejüleg természet- és társadalomtudomány, mert tárgya, a földrajzi környezet olyan sajátos tértípus, melyet a természeti szférák és a társadalom kölcsönhatás-rendszere jellemez" (SzABó J. 1992). A földrajz mint tudomány nehezen definiálható, mivel éppen azért különleges az ismeretanyaga, mert szerteágazó, és egyidőben több tudománnyal létesít közvetlen kapcsolatot. Ehhez kell a földrajzi gondolkodás, hogy mindezen diszciplínák értelmezhetők legyenek és összeálljanak egyetlen, térben értelmezhető komplex rendszerré. A földrajzi gondolkodás egyik alapja a szintetizáló szemléletmód, mert a különböző tudományterületek gondolkodásmódjának összehangolása, szintézise nélkül nem értelmezhetők ezen ismeretanyagok, így is nagy közöttük az elvi távolság. E távolság mégis áthidalható, mert a földrajzi szemléletmód elvi köteléket jelent a földrajzon belül azzal, hogy szintézist alkot, a komplexitás a látásmód döntő meghatározója (SzABó J. 1992). Ez az elvi kapocs tartja egyben ezt a meglehetősen heterogén tudományt. 
A földrajzi gondolkodás elsajátításában legmeghatározóbbak a földrajz tantárgy keretében lévő tanítási órák. A földrajzórákon a tanítási-tanulási folyamat révén sajátíthatják el a tanulók a szintézisben való gondolkodást. A földrajz tantárgy talán még nehezebben definiálható, mint a fö alapját képező tudomány, ugyanis a tantárgy több olyan tudományterületet - földtudományok, gazdaságtudományok, szociológia, statisztika, néprajz - is integrál, amelyeknek nincs saját, önálló tantárgyuk a köznevelési rendszerben (MAKÁDI M. 2005). Leszögezhető, hogy a földrajz tantárgy tartalmi szempontból jelentősen túlmutat a földrajztudományon, mivel ismeretanyaga még szerteágazóbb, továbbá még erőteljesebben érezhetővé válik a földrajz kettős természete, azaz hogy nemcsak természet-, hanem társadalomtudomány is (MAKádi M. - HoRváth G. 2011). Megállapítható, hogy a földrajz tantárgy nem kizárólag a térbeliséget közvetíti a tanulók számára annak minden természeti és társadalmi jelenségével, folyamatával, hanem azt is, hogy a világot összetettségében érdemes vizsgálni, hogy nem elég specialista módon elemezni természeti és társadalmi folyamatokat, jelenségeket, hanem generalista módon, komplexitásában is szemügyre kell venni, mert enélkül nem kaphatunk teljes képet.

A földrajz szemléletmódja, értékrendszere lehetővé teszi, hogy betöltsön egyfajta híd szerepet a tudományok és a tantárgyak között, ezzel közvetlen kapcsolatot teremtve a természet- és a társadalomtudományok, a reál és a humán tantárgyak között (MAKÁDI M. 2005, 2020). Ezen szerep kiváló lehetőség lehetne a tanulók számára, hogy a természettudományos tantárgyakból (biológiából, kémiából, fizikából, matematikából) elsajátított ismeretanyagot összekapcsolhassák, szintézist teremtsenek a társadalomtudományos ismeretanyagokkal, értékrendszerekkel, amelyeket leginkább a történelem és az etika tantárgyak keretén belül sajátíthattak el. Azonban mivel a tantárgy egyik legfőbb problémája, hogy a gimnázium 10. osztályában alapvetően befejeződik a tanítása-tanulása (egyéb középiskolatípusokban előfordul, hogy meg sem jelenik önálló tantárgyként), ezáltal időben megelözi azokat a tantárgyakat, amelyek ismeretanyagának és értékrendszerének szintézisét megvalósíthatná. Ezáltal a földrajz tantárgy nem tudja betölteni összegző, generalizáló szerepkörét, hanem sokkal inkább elökészíti a többi specialista látókörű tantárgy oktatását, megalapozza a természettudományok és a társadalomtudományok későbbi ismeretanyagát (MAKÁDI M. - HoRváth G. 2011, in TEPERICs K. 2015).

A 2020-as Nemzeti alaptanterv megjelenésével új kihívásokkal szembesült a földrajz tantárgy. A megváltozott tantervi környezet egyaránt támaszt előnyöket és hátrányokat is a földrajz és a tantárgyi integráció számára. Az új, módosított NAT hátrányos következménye, hogy a lassan már megszokott tendencia folytatódásával a földrajzi óraszámok tovább csökkentek, így a földrajzi ismeretanyag feldolgozására, a 
földrajzi gondolkozás kialakítására és a tantárgyak közötti integrációra a korábbiaknál is kevesebb idő jut. További negatívum, hogy a földrajz elvesztette önálló műveltségi területét, viszont önálló részterületként van jelen a Természettudomány és földrajz műveltségi területen belül. Ezzel tulajdonképpen elismerésre került kiemelt jelentősége, hogy ez a tantárgy képes integráló és szintetizáló szerepkörre (bár utóbbira egyre kevésbé), illetve hogy ez a tantárgy az, amely egyedüliként közel azonos súllyal egyaránt tartalmaz természet- és társadalomtudományi ismereteket. A módosított tantervbe bekerült egy új fogalom, a tanulási eredmény, ami a tanulási folyamat végeredményeképp megszülető tudásra reflektál (FARSANG A. - ÜTőNÉ VISI J. 2020). Az átdolgozott Nemzeti alaptanterv sokkal inkább a tanulási eredményre helyezi a hangsúlyt, ezzel tulajdonképpen teret enged a földrajztanároknak abban, hogy az adott csoportra szabva határozzák meg, hogy mit, milyen sorrendben, milyen mélységben és hány órában tanítanak meg (természetesen a kerettanterv által meghatározott időkeretek betartásával). Lényeges pozitívuma az új tantervi környezetnek, hogy lehetőség nyílt a 11. osztályban való földrajztanulásra-tanításra heti két órában, mivel az új tantervek szerint heti két órában szabadon indítható valamelyik természettudományos tantárgy (FARSANG A. - ÜTőNÉ VISI J. 2020). Ennek következtében lehetséges, hogy a jövőben újra többen választják a földrajzot érettségi tantárgyként. Összességében az mondható, hogy alapvetően kevesebb az időkeret a tantárgyi integráció számára, de a tanulási eredményre való fókuszálás és a 11. évfolyamon való tanítás lehetősége segíti a tantárgyak közötti kapcsolatteremtést.

\section{TANTÁRGYI INTEGRÁCIÓ}

A tantárgyi integráció egy gyüjtőfogalom, amibe sokféle didaktikai nézet és tantervi modell belefér. CHR APPÁN M. az alábbi módon definiálta a tantárgyi integrációt: „... olyan tartalomkiválasztási, tananyag-elrendezési módszer, amelyik két vagy több diszciplináris tantárgyat von össze egy új tárgy keretei közé úgy, hogy az eredeti tantárgyak határvonalai részben vagy teljesen feloldódnak, bár azok sajátos arculata nem mosódik el, és az érintett diszciplínáktól származó ismeretek közös struktúráihoz tartozó alapfogalmakat és összefüggéseket egységes szemlélettel tárgyalja úgy, hogy a tananyag tartalmai, a módszerek és a tevékenységek valamilyen vezérmotívum (rendszerképzö elv) alapján rendezödnek a tantervben és a tanitási-tanulási folyamatban egyaránt” (CHRAPPÁN M. 1998. p. 68.). A tanulmányomban ennek a gyüjtőfogalomnak az egyik legalapvetőbb eleméhez nyúltam vissza, azaz a tantárgyak közötti kapcsolatteremtéshez, amely a tanteremben valósul meg, és amit a földrajztanár értékrendszere és attitüdje határoz meg. 
A földrajztanárok szakpárjai között leggyakoribbak a földrajzi tartalommal erőteljes kapcsolatban lévő tantárgyak, a biológia és a történelem. Ezen két tantárgy, illetve tanárszak szemléletmódjában és ismeretanyagában is jelentősen különbözik egymástól. Emiatt a két nagy, az oktatásban jelen lévő tudománycsoport (humán és reál; bölcsészettudományok és természettudományok) között hidat képező földrajz tantárgy szemléletmódját és a tanításban egyes témakörök közötti hangsúlyokat módosítani képesek, ha abból indulunk ki, hogy a tanárok a szakpárjaikat a saját beállítottságuknak és viszonyulásuknak megfelelően választják.

Az előző gondolatokból adódóan erősen valószínűsíthető, hogy mindennapi tanítási gyakorlatuk során a biológia-földrajz szakpárral rendelkező tanárok (a kitöltők 27,5\%-a) a természettudományok felé „,billentik a mérleg nyelvét”, míg a történelemföldrajz szakosok $(21,0 \%)$ a társadalomtudományok felé.

\section{A KUTATÁS ÉS A TANULMÁNY HIPOTÉZISE}

Az előzőek ismeretében alapvetően arra voltam kíváncsi, hogy a földrajzot tanító tanárok másik szakja milyen mértékben befolyásolja azt, hogy hogyan, milyen összefüggések láncolatán keresztül juttatják földrajzi tudáshoz a tanulókat. Mivel a földrajz tantárgy kettőssége lehetővé teszi, hogy a tanár az egyik vagy másik irányába tolja el a hangsúlyokat, az érték- és ismeretrendszer alapjait, az a kérdés vetődött fel bennem, hogy a földrajzot tanító tanárok összefüggésbe hozzák-e a földrajzzal az általuk tanított másik tantárgy(ak) szemléletét, ismeret- és értékrendszerét. Természetesen saját általános iskolai és gimnáziumi élményeim is adnak egy választ ezekre a kérdésre. Azt tapasztaltam, hogy a tanár másik szakja hatással van a földrajz tanítási folyamatára, a földrajzi témák összefüggéseinek tanításakor a másik szakhoz köthető elemeket is beilleszti a tanítási folyamatba.

Mint említettük, a földrajz tantárgy egyik fö gondja, hogy nem jó idősávban tanulják a tanulók, ez azonban - tekintettel a tantárgy tartalmi sokszínűségére - tantárgyi integrációval némileg ellensúlyozható. Magyarországon jelenleg több olyan középfokú intézmény van, ahol valamilyen módon tagozatokba sorolva folyik az oktatási-nevelési munka. Gimnáziumok esetében gyakoriak a humán és a reál tagozatok, ahol egyes tantárgyak emelt óraszámban vannak jelen. A középiskolába való jelentkezéskor általában a tanulók az attitüdjüknek megfelelően választják meg az intézményt, a tagozatot, így a humán tagozatra alapvetően humán, míg a reál tagozatokra reál, természettudományos beállítottságú, gondolkozású, érdeklődésű tanulók jelentkeznek. Ebből kifolyólag a különböző tagozatokon már tudatosan úgy lehetne alakítani a földrajzi ismeretanyagot, a szemléletmódot, a tartalmi és fejlesztési hangsúlyokat, hogy az a lehető 
legközelebb legyen a tanulók beállítottságához, ezzel könnyebbé téve a földtudományok megértését, a folyamatok komplexitásban látását. A szintetizáló jelleget - ha nem is teljesen, de - elvi és szemléleti szinten elérhetné a földrajz tantárgy. A szintetizálásból a tanulók profitálhatnak abban a tekintetben, hogy a földrajzi folyamatok, rendszerek, ismeretek sokkal közelebbivé és kézzelfoghatóbbá válhatnak számukra. Továbbá a már korábban megtanult ismereteik között kapcsolatot teremthetnek és az új megközelítéssel egy ismeretrendszerbe tudják elhelyezni az újonnan megtanult, elsajátított elemeket a szintetizálásnak köszönhetően.

\section{A KUTATÁS ANYAGA, MÓDSZERTANA}

A földrajztanárok körében végzett kutatás során online megosztható és online megválaszolható önkitöltős Google kérdőíveket használtam. Az alkalmazott kérdések döntően megjelölendő válaszokat tartalmaztak. Volt olyan kérdés, ahol csak egy választ lehetett kiválasztani, míg volt olyan is, ahol többet. Voltak nyílt kérdések is, amelyekre a tanárok rövid válaszokat adhattak. Mindezek azt szolgálták, hogy minél többféle szempontból vizsgálhassam, hogy a földrajzot tanító tanárok másik szakja mennyiben, miként jelenhet meg a földrajztanítás folyamatában. Továbbá voltak általánosabb jellegü kérdések is, amelyek átfogó képet mutathatnak a kitöltőkről, például hogy milyen a tanárok életkor szerinti rétegződése, vagy éppen az ország milyen méretű településén tanítanak.

A két kérdéssort csatolmányként elektronikusan küldtem el a már előre kiválasztott oktatási intézményeknek. A kiválasztásban törekedtem arra, hogy lakosságszámot, funkciót, illetve státuszt figyelembe véve minden településkategóriát, megyét és régiót, továbbá minden iskolai kategóriát (fenntartó és szint figyelembevételével) elérjen a kérdéssorom. Ez annak érdekében volt fontos, hogy minél reprezentatívabbá váljon a mintavétel, így tisztább képet kaphassak a felvetett kérdésekről. A településkategóriák a következők voltak: főváros; megyeszékhely, megyei jogú város; középváros (15 000-100 000 fö); kisváros (5000-15 000 fö); község (5000 fö alatt). Véletlenszerüen választottam ki megyénként a városokat, majd városonként az iskolákat, annak figyelembevételével, hogy a lehető legtöbb féle, legsokszínübb fenntartói hátteret (állami, alapítványi, egyházi, minisztériumi, egyetemi fenntartás) és iskolaszintet (általános iskola, középiskola) tudjam vizsgálni. A városok kiválasztásánál az volt a rendező elv, hogy megyénként minden településkategóriából többet elérjen a kérdőív, tükrözve a településkategóriák körülbelüli országos arányát. A kérdőívek névtelenek voltak, a településnevekre sem kérdeztek rá.

A kérdőív kérdései három csoportba sorolhatók. Az első csoport a kitöltők általános adatait tartalmazza (településkategória, a kitöltő korosztálya, neme, szakjai). A második 
csoport a földrajzi témakörökkel, fontossági és preferenciális sorrendekkel foglalkozik, a harmadik pedig a módszertani eszközök, megoldások és segédanyagok használatát térképezi fel. Jelen tanulmányban a második kérdéscsoport két fö elemét mutatom be. A földrajztanároknak tíz földrajzi témakört kellett fontossági sorrendbe rendezni, amiből megismerhetők a prioritásaik a témakörök tekintetében. Az ezután következő kérdésben a témakörök közül ki kellett választaniuk azt a témakört, amelyet a leginkább szeretnek tanítani. Válaszaikból megállapítható, hogy az egyes témakörök milyen szinten kedveltek, melyeket preferálják és melyeket nem szeretnek tanítani. Végső soron két sorrend vizsgálható: a fontossági és a preferenciális. Mindkét megvilágítás, illetve felállított sorrend fontos lehet a tantárgyi integráció vizsgálatakor, mivel befolyásolják, hogy mely témakörök milyen súlyt kapnak a tanítási-tanulási folyamatban.

Ebben a tanulmányban kiemelten foglalkozom a következőképpen megfogalmazott kérdéssel: „Mennyire tartja fontosnak az alábbi földrajzi témaköröket? Kérem, jelölje 1-10 közötti értékekkel (1 - legkevésbé, 10 - legfontosabb)!”. Ez a kérdés és a hozzá megadott tíz kategória a tanárok témakörökkel kapcsolatos fontossági sorrendjét (prioritását) volt hivatott felmérni. A válaszadóknak minden téma esetében választaniuk kellett a 10 kategóriából aszerint, hogy mennyire tartják fontosnak azt. Tehát itt egyértelmü hozzárendelés történt, azaz minden téma esetében egy érték volt megjelölhetö és minden értékhez egy téma volt rendelhető (ahol mind a pontszámok, mind a témák a kérdésen belül csak egyszer szerepeltek). A kérdésben az alábbi témák szerepeltek: térképészeti ismeretek, csillagászati földrajz, a Föld és a kontinensek természetföldrajza, Európa és országainak természetföldrajza, globális gazdaságföldrajz, regionális gazdaságföldrajz, globális társadalomföldrajz, regionális társadalomföldrajz, nemzetközi szövetségi és integrációs szervezetek, rendszerek, környezet- és természetvédelem. Ezen témaköröket a 2012-es Nemzeti alaptantervhez igazodó kerettantervek (általános iskolai, gimnáziumi, szakgimnáziumi, szakiskolai) alapján állítottam össze úgy, hogy a módosított NAT-tal is kompatibilisek maradjanak. A témaköröket úgy határoztam meg, hogy tükrözzék a földrajztanítás különböző területeit aszerint, hogy milyen arányban van, illetve volt jelen a tantárgy ismeretanyagán belül. További cél volt, hogy a megállapított témakörök ismeretrendszerüket, szemlélet- és gondolkodásmódjukat tekintve minél homogénebbek legyenek.

A mintavételezéskor a 2012-es Nemzeti alaptanterv nevezéktanát alkalmaztam az iskolatípusok meghatározásánál, de mivel a 2020-as NAT nevezéktana módosításokat is tartalmaz, így a következőket is: a szakgimnáziumok (korábbi szakközépiskolák) technikumok lettek (továbbá ezek is átkerültek a képzésnek megfelelő minisztérium fenntartásába), a szakiskolák szakközépiskolák lettek. Összesen 756 intézményt kerestem fel, ahonnan 98 válasz érkezett. A válaszok kis száma több tényezőnek is tulajdonítható. 
A kérdőívek az intézmények publikus e-mail-címére érkeztek, amire sokféle információ érkezik napi rendszerességgel, így a kérdőív elveszhetett a sokaságban, továbbá megakadhatott az e-mail-fiókot kezelők és a szaktanárok között is. Tapasztalataim alapján a kitöltési hajlandóság is változó volt a tanárok körében, de egészében véve inkább csak kismértékü.

\section{A TANÁROK VÉLEMÉNYEI SZAKJAIK SZERINTI BONTÁSBAN}

Mint azt korábban említettem, az a feltételezés, hogy a földrajztanárnak a földrajz melletti másik szakja hatással van a földrajztanítás tartalmára és szemléletére, csak akkor állhatja meg a helyét, ha a szakok, szakirányok alapján történő csoportosításban a tanárok között jelentős különbség mutatkozik. Szakok alapján három csoportba soroltam a tanárokat aszerint, hogy a földrajz mellett milyen más szakkal rendelkeznek: a tisztán reál orientáltságú, a tisztán humán irányú szakokkal rendelkezők, és azok, akik nem egyértelmüen besorolhatók (ők alkotják a vegyes csoportot). Az utóbbi csoportba azok tartoznak, akik kettőnél több szakot jelöltek meg, és amelyek között vegyesen van humán és reál szak is (például földrajz-történelem-biológia); vagy készségtárggyal (például rajz vagy testnevelés) rendelkeznek.

Ahogy fentebb már említettem, a kérdésekre adott válaszokban a kitöltők tíz témakört jelölhettek meg, amelyeket több szempont alapján határoztam meg. Alapvető volt, hogy a témakörök a lehetö legnagyobb mértékben lefedjék a földrajz tantárgy témáit. Emellett fontos volt, hogy a témakörök szemléletmódjuk és összefüggésrendszerük szerint homogének legyenek. Így három jelentős témakörcsoportot alakítottam ki: természetföldrajz, társadalomföldrajz és egyéb.

- Természetföldrajz: az általános és globális szemléletü A Föld és a kontinensek természetföldrajza és a regionális szemléletü Európa és országainak természetföldrajza tantervi témaköröket foglalja magában. Előbbi témakör az általános természetföldrajzot és az Európán kívüli országok természetföldrajzát, míg utóbbi Európa és azon belül a Kárpát-medence és Magyarország természetföldrajzát tartalmazza. A környezet- és természetvédelem témakörét a természetföldrajzi témakörökkel együtt vizsgáltam, noha nyilvánvaló, hogy jelentőségét és multidiszciplinaritását tekintve mind a természet-, mind a társadalomföldrajz témakörcsoportjához sorolható lenne.

- Társadalomföldrajz: e csoportban is globális és regionális témakörpárokat határoztam meg, a globális és regionális társadalomföldrajz, előbbi az általános társadalmi folyamatokat és ismereteket foglalja magába, míg utóbbi például a városföldrajzot és a regionális tudományok témáit tartalmazza. Továbbá a gazdaságföldrajz globális és regionális része külön témakörként kerültek meghatározásra, habár a társadalom- 
földrajz része a gazdaságföldrajz a hagyományos felosztásban, de a kutatás során utóbbit kiemeltem a társadalomföldrajzból, mert a gazdaságföldrajz több ponton inkább a természettudományok ismeretrendszerével korrelál és inkább a természettudományos szemléletmód jellemzi.

- Egyéb: az előző két csoportba egyértelmüen be nem sorolható témakörök között vannak hagyományosan a földrajz által tanított témakörök, mint a Csillagászati földrajz vagy a Térképészeti ismeretek, továbbá a Nemzetközi szövetségi és integrációs szervezetek, rendszerek témakör került ebbe a kategóriába, amely az ENSZ, EU, NATO szervezetekkel foglalkozik és ezen témakör az, ami jelentősen hozzájárul az állampolgári ismeretek fejlesztéséhez.

A kérdőív összeállításakor még a 2012-es Nemzeti alaptanterv volt érvényben, de a témaköröket igyekeztem úgy összeállítani, hogy azok az akkor még csak megjelenés elött állt új tantervi környezetnek is meg tudjon felelni, azaz a 2020-as alaptantervvel is kompatibilis legyen.

\section{A TANÁROK ÁLTAL FELÁLLÍTOTT FONTOSSÁGI SORRENDEK}

Előzetesen megállapítható, hogy az éghajlatváltozást és a hozzá kapcsolódó természeti, gazdasági, társadalmi problémákat - mint a 21. század legégetőbb, legfontosabb, a Föld egészére és a teljes társadalmunkra kiható, a földrajz tantárgy témaköreihez tartozó problémák - szinte minden csoportban a legfontosabbnak jelölték a tanárok. Továbbá azt is megállapíthatjuk, hogy a természetföldrajzi témakörök szinte mindenhol magas pontszámot értek el, a választott témakörök rangsorának első felébe tartoztak. A két utolsó helyen a nemzetközi szövetségi és integrációs szervezetek, rendszerek és a csillagászati földrajz témakörök állnak, tehát a földrajzot tanítók körében ezek a legkevésbé fontosak. A térképészeti ismeretek (mint a földrajz tantárgy egyik hagyományos témaköre) állandóan „vándorol” a különféle szempontú tanári csoportosításokban, így az a következtetés vonható le, hogy a földrajztanárok általánosságban nehezen tudják megtalálni a térképészeti ismeretek helyét a tantárgyban.

Az 1. táblázat mutatja az összes kitöltő által adott válaszok átlagát csoportosítások nélkül, ami viszonyítási alapot szolgáltat a későbbi szakok szerinti összehasonlításhoz, továbbá a témakörök összesített fontossági sorrendje kiindulópontot jelenthet a tantárgyi integráció vizsgálatához.

A táblázatban kiemelten (félkövérrel szedve) a tanárok által legfontosabbnak ítélt három kategória és a legkevésbé fontos kategória látható. Ezek sorrendben (kezdve a három legfontosabbnak ítélttel): a környezet- és természetvédelem, a Föld és a kontinensek természetföldrajza, Európa és országainak természetföldrajza, a legkevésbé 
fontos az összesített sorrendben a nemzetközi szövetségi és integrációs szervezetek, rendszerek, amit fele olyan fontosságúnak tartanak, mint a környezet- és természetvédelmet. A környezet- és természetvédelem által elért legmagasabb pontszám azzal indokolható, hogy a jelenkor egyik legnagyobb földrajzi problémája a globális éghajlatváltozás. E kifejezetten szerteágazó témakör egyre fontosabbá válik a társadalom számára, mivel annak egészét fenyegeti. A másik két magas pontszámot elért témakör természetföldrajzi vonatkozású. Ezek valószínüleg azért értek el ilyen előkelö helyezést, mert mindkét tudományterület hagyományosan része az általános iskolai és a középiskolai földrajztanításnak, valamint mindkét iskolaszinten e témakörökkel kezdődik a földrajztanulás folyamata, továbbá ezek képviselik leglátványosabban a természettudományi irányvonalat. Minthogy a földrajzot általánosságban természettudományos, illetve reál tantárgyként határozzák meg, szükségszerü a magas rangsorolásuk. A tanárok körében a legkevésbé fontosnak tartott témakör a nemzetközi szövetségi és integrációs szervezetek, illetve rendszerek; a témakör - erős társadalmi-történelmi vonatkozásai mellett - vélhetően azért került a rangsor végére, mert a jóval nagyobb óraszámú történelem tantárgy is tanítja, így valószínúleg a földrajztanárok nem tartják ezt kiemelt jelentöségünek, mindemellett a témakör kevés földrajzi vonatkozással rendelkezik a köznevelés szintjén. Továbbá ez - ellentétben az előző témakörökkel - csak a középiskolákban tananyag, így az általános iskolai tanárok vélhetően nem is vették figyelembe. Pedig kifejezetten fontos lenne, hogy - főleg a középiskolás tanulók - átlássák a világ országainak szövetségi rendszereit és azok földrajzi vonatkozásait. Mivel hazánk is része a világ egyik legmeghatározóbb integrációs szervezetének, az Európai Uniónak, így ennek értelmezése, földrajzi kontextusba ágyazása fontos lenne a Nemzeti alaptantervben szereplő több alapkompetencia kialakítása szempontjából is. Azt is figyelembe kell venni, hogy

\begin{tabular}{|c|r|r|}
\hline Sorrend & Témakör & Atlag \\
\hline $\mathbf{1}$ & Környezet- és természetvédelem & $\mathbf{7 , 7 3}$ \\
$\mathbf{2}$ & A Föld és a kontinensek természetföldrajza & $\mathbf{6 , 7 2}$ \\
$\mathbf{3}$ & Európa és országainak természetföldrajza & $\mathbf{6 , 2 1}$ \\
$\mathbf{4}$ & Térképészeti ismeretek & 5,76 \\
$\mathbf{5}$ & Globális társadalomföldrajz & 5,57 \\
$\mathbf{6}$ & Globális gazdaságföldrajz & 5,40 \\
$\mathbf{7}$ & Regionális társadalomföldrajz & 5,16 \\
$\mathbf{8}$ & Regionális gazdaságföldrajz & 5,12 \\
$\mathbf{9}$ & Csillagászati földrajz & 3,74 \\
$\mathbf{1 0}$ & Nemzetközi szövetségi és integrációs szervezetek/rendszerek & $\mathbf{3 , 5 9}$ \\
\hline
\end{tabular}


a tanárok jelentős hányada felsőoktatási tanulmányai folyamán csak keveset foglalkozott ezzel a témakörrel, mivel akkor még Magyarország nem volt tagja a szervezetnek, továbbá a jelenlegi tanárképzésben sem kap nagy hangsúlyt a hallgatók ezen témakörrel kapcsolatos földrajzi tudásának elmélyítése.

A továbbiakban vizsgáljuk meg a rangsorokat a földrajztanárok második tanított szakja szerinti bontásban! A 2. táblázatból jól látható, hogy ha ez egy humán tantárgy (az ilyen tanárokat a továbbiakban nevezzük „humán szakosnak”), akkor megtörik az uralkodóan természetföldrajzi jellegű témák hegemóniája. Ezen kívül látható, hogy mind a három nagy földrajzi tudományágon (természetföldrajz, társadalomföldrajz, gazdaságföldrajz) belül a globális oldal van magasabban a rangsorban a regionális oldallal szemben. E megállapítás azért fontos, mert a globális témakörök tárgyalásuk és értelmezésük módját tekintve minden esetben nagyobb mozgásteret adnak a tanítási-tanulási folyamatban, kevésbé merev témakörök, mint regionális párjaik, amelyek sokkal tényszerűbbek, mondhatni „reálosabbak”. Továbbá a térképészeti ismeretek a humán szakosok körében sokkal kevésbé fontosak, mint az összes tanár körében (1. táblázat), vélhetően azért, mert feldolgozási módját túlságosan behatároltnak tartják. Ezek mellett a történelem tantárggyal szoros viszonyban lévő nemzetközi szövetségi és integrációs szervezetek, illetve rendszerek témaköre, ha csak egy hellyel is, de feljebb került, vélhetően azért, mert a történelmi vonatkozásai miatt vonzóbb témának számít egy bölcsész számára, mint például a glintvonal értelmezése.

Az 1. és a 2. táblázatot összevetve feltűnő, hogy a legnagyobb és a legkisebb értékek különbsége az összes tanár átlagában 4,1, míg a humán szakosok körében csak 3,2, és utóbbiaknál általánosságban is csak viszonylag kis különbség van a szomszédos értékek

\begin{tabular}{|c|r|r|}
\hline Sorrend & Témakör & Átlag \\
\hline $\mathbf{1}$ & Környezet- és természetvédelem & $\mathbf{7}$ \\
$\mathbf{2}$ & Globális társadalomföldrajz & $\mathbf{6 , 2 8}$ \\
$\mathbf{3}$ & A Föld és a kontinensek természetföldrajza & $\mathbf{5 , 8}$ \\
$\mathbf{4}$ & Globális gazdaságföldrajz & 5,76 \\
$\mathbf{5}$ & Regionális gazdaságföldrajz & 5,6 \\
6 & Regionális társadalomföldrajz & 5,6 \\
7 & Térképészeti ismeretek & 5,44 \\
8 & Európa és országainak természetföldrajza & 5,28 \\
9 & Nemzetközi szövetségi és integrációs szervezetek/rendszerek & 4,44 \\
\hline $\mathbf{1 0}$ & Csillagászati földrajz & $\mathbf{3 , 8}$ \\
\hline
\end{tabular}

2. táblázat. Az egyes témakörök fontossági sorrendje a humán szakpárral rendelkezö földrajztanárok szerint (szerk. Varga D.) 
között, föleg a táblázat középső elemei esetében. Ennek az lehet az oka, hogy a humán szakosok a különböző témaköröket a reál szakosokhoz képest többféleképpen állították sorba, emiatt a maximum értékben 1,6 pontos eltérés van a két csoport között. Továbbá az is kiemelhető, hogy a humán szakosok körében a társadalomföldrajzi témakörök a leginkább fontosak. Rangsoraik összesítésében a globális társadalomföldrajz a második helyre került, míg a regionális társadalomföldrajz a regionális gazdaságföldrajzzal megegyező értékkel az ötödik-hatodik helyen áll. Mindezek alapján megállapítható, hogy a humán szakos tanárok a földrajznak azokat a témaköreit tartják fontosnak, amelyek közvetlen kapcsolatban állnak a humán tantárgyakkal, legfóképp a történelemmel és a társadalomtudományokkal.

A reál szakos tanárok rangsorainak esetében is szembeötlő különbségek vannak az összesítéshez és a humán szakosokéhoz képest, utóbbihoz viszonyítva még erősebbek az eltérések (3. táblázat). A témakörök sorrendjét tekintve azt láthatjuk, hogy itt is a természetföldrajzi témakörök állnak a környezet- és természetvédelem után. Viszont az összesítéshez, de legfőképp a humán szakosok fontossági sorrendjéhez képest a társadalomföldrajzi témák leértékelődnek, illetve a regionális témák előzik meg a globális párjukat a gazdaság- és társadalomföldrajz tekintetében. A legnagyobb és a legkisebb értékek különbsége $(5,24)$ jóval magasabb az összesítetthez és a humánosokéhoz képest, emellett itt a maximum 8,60. Ezek alapján arra lehet következtetni, hogy a reál szakos tanárok a humán szakosokhoz képest sokkal következetesebben, többször rangsorolták körülbelül ugyanarra helyre ugyanazokat a témaköröket. Megállapítható tehát, hogy a reálosok esetében is jelentkezik a saját vonaluk a fontossági rangsort tekintve, a sokkal magasabb pontszámot elérő környezet- és természetvédelemmel, a természetföldrajzi

\begin{tabular}{|c|r|r|}
\hline Sorrend & Tómakör & Átlag \\
\hline $\mathbf{1}$ & Környezet- és természetvédelem & $\mathbf{8 , 6 0}$ \\
$\mathbf{2}$ & A Föld és a kontinensek természetföldrajza & $\mathbf{6 , 8 3}$ \\
$\mathbf{3}$ & Európa és országainak természetföldrajza & $\mathbf{6 , 6 2}$ \\
$\mathbf{4}$ & Térképészeti ismeretek & 5,43 \\
$\mathbf{5}$ & Regionális gazdaságföldrajz & 5,36 \\
6 & Globális gazdaságföldrajz & 5,19 \\
$\mathbf{7}$ & Regionális társadalomföldrajz & 5,19 \\
$\mathbf{8}$ & Globális társadalomföldrajz & 5,05 \\
$\mathbf{9}$ & Csillagászati földrajz & 3,38 \\
$\mathbf{1 0}$ & Nemzetközi szövetségi és integrációs szervezetek/rendszerek & $\mathbf{3 , 3 6}$ \\
\hline
\end{tabular}

3. táblázat. Az egyes témakörök fontossági sorrendje a reál szakpárral rendelkezö földrajztanárok szerint (szerk. Varga D.) 
témakörök második és harmadik helyével, azzal, hogy a regionális témakörök megelözik globális párjukat a gazdaság és társadalomföldrajz témaköreit tekintve, továbbá az, hogy a gazdaságföldrajzok magasabb értékeket kaptak, mint a tisztán humán jellegünek nevezhető társadalomföldrajzi témakörök.

A táblázatok adatai alapján egyértelműen megállapítható, hogy a témakörök tanárok által kialakított rangsorát leginkább a szakjuk, szakjaik befolyásolják. Ezáltal - ha elfogadjuk azt a nagyon valószínű tényt, hogy a tanár arra fekteti a hangsúlyt a tanítás során, amit fontosnak tart - valószínüsíthető, hogy a fontosabbnak tartott tartalmak terén egy erős tantárgyak közötti integráció valósul meg a földrajz és ezen fontosabb tartalmakhoz közelálló tantárgyak között.

\section{A TANÁROK ÁLTAL FELÁLLÍTOTT PREFERENCIÁLIS SORRENDEK}

A tanári attitűd és a földrajzi témakörök kapcsolatát több kérdésen keresztül mértem fel. Erre azért volt szükség, hogy látható legyen a viszonylag objektív prioritások mellett mely témakörök jelennek meg a preferenciák élén, továbbá, hogy mely témaköröket szeretik kevésbé tanítani a tanárok.

A Föld és a kontinensek természetföldrajza kiemelten elötérbe helyezett téma a földrajztanárok körében. Az eddig legfontosabbnak tartott témakört, a környezet- és természetvédelmet a preferált témakörök rangsorában jóval hátrébb sorolták. Ez azért érdekes, mert noha a legfontosabbnak tartják, mégsem ezt szeretik a leginkább tanítani. $\mathrm{Az}$ állhat a hátterében, hogy e témakörben kevésbé stabil ismeretekkel rendelkeznek a pedagógusok, hiszen az ő képzésük időszakában ezek a kérdések kevésbé voltak aktuálisak, hangsúlyosak. Ha ezt a kimutatást is megnézzük szakok szerinti bontásban, akkor különbségeket fedezhetünk fel, ahogy elözőleg a fontossági rangsorokat (prioritásokat) tekintve, úgy most a preferenciáknál is.

A humán szakos tanárok adatainak (kék színnel az 1. ábra diagramján) megfigyelése alapján jól látható, hogy a tíz választható témakörből csak kilenc szerepel. A kimaradó témakör a várakozásoknak megfelelően természetföldrajzi, azaz reál tartalmú. Látható, hogy a Föld és a kontinensek természetföldrajza itt is erősen preferált, és a globális témák ebben az esetben is jobban szerepeltek a regionális párjukhoz képest.

A reál szakos tanárok válaszaiban (narancs) is felfedezhetők minták az általuk felállított fontossági sorrendnek megfelelően. Összehasonlítva az eddigi oszlopokkal, itt - a fontossági rangsorhoz hasonlóan - nagyobb a százalékos értékek terjedelme, mint a humán szakosoknál. Továbbá a reál szakosoknál is a megjelölhető tíz témakörből csak kilenc témakör képviselteti magát. A kimaradó témakör a társadalomtudományok felé tendáló regionális társadalomföldrajz, amely közelebb áll a humán szakosokhoz ismeretanyaga és 


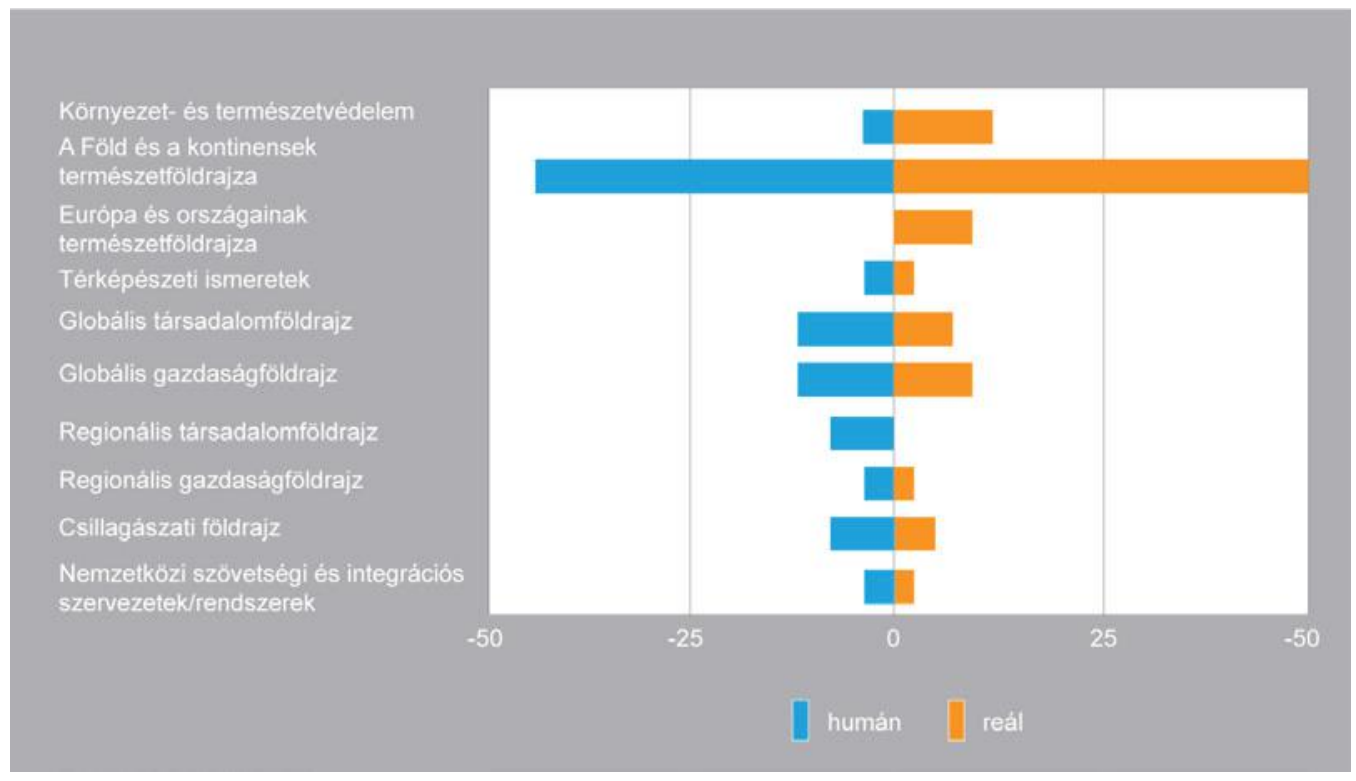

1. ábra. Témapreferencia a humán és a reál szakos tanároknál (szerk. Varga D.)

logikai felépítése miatt. A reál szakosoknál is a Föld és a kontinensek természetföldrajza témakör a legkedveltebb, amit itt a környezet- és természetvédelem követ.

\section{ÖSSZEGZÉS}

Összességében a földrajz óraszámának csökkentése tovább nehezíti a tantárgy helyzetét, elveszi a szintetizálás lehetőségét azzal, hogy a 9-10. évfolyamon zajlik a földrajztanítás, viszont egyes lehetőségek, mint például a 11. osztályban való tanítási lehetősége, továbbá a tanulási eredményre való reflektálás előremutatók abban a tekintetben, hogy teret engednek a tantárgyi integráció erősödésének.

A kérdőíves kutatás és a tanulmány alapján megállapítható, hogy a tantárgyi integráció jelen van a földrajztanításban, azaz a földrajztanárnak a földrajz melletti másik szakja hatással van a földrajztanítás tartalmára és szemléletére. Mint láthattuk a tanárok prioritásai és preferenciái nagyban függnek attól, hogy milyen szakjuk van a földrajz mellett. Habár a kiküldött kérdöíveknek kis része került kitöltésre (ami demonstrálja a tanárok országosan alacsony kitöltési hajlandóságát), úgy gondolom megfelelő mennyiségű és minőségű adat gyűlt össze a jelenség első feltérképezésére.

Véleményem szerint ezen az eddig kevésbé kutatott területen még sok kiaknázatlan lehetőség van, továbbá a jövőben még fontos megfigyelések sora szükséges ahhoz, hogy azt a tanulók számára hasznosíthatóvá tehessük. Az integráció ezen alapvető és 
a tanulókhoz legközelebb álló szintjén, ami tartalmi és szemléleti kapcsolatteremtést jelent más tantárgyakkal, mindenképpen egy új lehetőség lehet a földrajz módszertárának tudatos bővítésére, ezzel elősegítve a tantárgy szintetizáló szerepét, ami a speciális helyzetéből adódik. A témában további kutatási lehetőségként felmerül annak vizsgálata, hogy a speciális tartalmú helyi tantervek mentén tanuló diákoknak milyen igényeik vannak, mennyire hatékony és hasznos a számukra földrajz integratív szellemben való tanítása. Ezen felül további feladat lehet az integratív földrajzórák hatékonyságának vizsgálata, a helyi tanterveknek a tanulók igénye és beállítottsága alapján való kialakítása, hogy a tagozatos rendszerü gimnáziumokban és a szakképző intézményekben (ahol van önálló földrajztantárgy) az osztályok profiljához lehessen igazítani és ezzel együtt könnyebben tanulhatóvá és érdekesebbé tenni a földrajzot.

Az integratív szellemben tartott földrajzórák azért lehetnek hasznosak, mert így a tanulók alapvető beállítottságához igazíthatjuk a tananyag hangsúlyait, ismeretrendszerét, továbbá jobban és könnyebben fel tudjuk kelteni, meg tudjuk tartani a tanulók érdeklődését a tanóráinkon. Azaz a tanárnak itt van lehetősége arra, hogy a tanulókat magával a tudással motiválja, mert ha a csoport általános beállítottságához igazítja az adott témakör tartalmát, akkor azt a tanulók könnyebben fogadják el és értik meg. Ez számukra könnyítheti a tanulási folyamatot azáltal, hogy a földrajzi ismereteket egy számukra könnyebben értelmezhető útvonalon érik el azzal, hogy a tanár olyan kitekintéseket, tantárgyközi kapcsolatokat visz bele a tanítási-tanulási folyamatba, ami a tanulók alapvető beállítottságához a leginkább közel álló.

\section{IRODALOM}

Chrappán Magdolna (2009): A természettudományos tantárgyi integráció. - Oktatáskutató és Fejlesztő Intézet, Budapest. https://ofi.oh.gov.hu/termeszettudomanyos-tantargyi-integracio (2020.12.17.)

FARSANG ANDREA - ÜTőNÉ VISI Judit (2020): Új kihívások a földrajzoktatásban. - Nemzeti alaptanterv és Kerettanterv 2020. - GeoMetodika 4. 2. pp. 33-46.

Makádi Mariann (2005): Földönjáró. Módszertani kézikönyv I. - Stiefel Eurocart Kft., Budapest. 200 p.

MAKÁdi MARiann (2020): A földrajztanítás módszertani alapjai 1. - ELTE TTK FFI, Budapest. 179 p. http://geogo.elte.hu/images/A_Foldrajztanitas_modszertani_alapjai.pdf

Makádi Mariann - Horváth Gergely (2011): A földrajz és a természettudományok. - Földrajzi Közlemények 135. 2. pp. 179-184.

SzABó József (1992): A természetföldrajz tárgya, céljai, tagolódása, tudomány-rendszertani helye. - In: Borsy Z. (szerk.): Általános természetföldrajz. Nemzeti Tankönyvkiadó, Budapest. pp. 7-23.

Teperics Károly - SÁriné Gál Erzsébet - Németh Gábor - Sütő László - Homoki Erika (2015): Földrajztanítás - Válogatott módszertani fejezetek. - Debreceni Egyetemi Kiadó, Debrecen. pp. 171-177. 
Kerettanterv a gimnáziumok 9-12. évfolyama számára. - https://www.oktatas.hu/kozneveles/kerettantervek/2020_nat/kerettanterv_gimn_9_12_evf (2020.11.08.)

110/2012. (VI. 4.) Korm. rendelet a Nemzeti alaptanterv kiadásáról, bevezetéséről és alkalmazásáról. Magyar Közlöny 2012. 66. pp. 10635-10847.

5/2020. (I. 31.) Korm. rendelet a Nemzeti alaptanterv kiadásáról, bevezetéséről és alkalmazásáról. Magyar Közlöny 2020. 17. pp. 290-447.

51/2012. (XII. 21.) számú EMMI rendelet 3. melléklet. Kerettanterv a gimnáziumok 9-12. évfolyama számára. https://kerettanterv.oh.gov.hu/03_melleklet_9-12/index_4_gimn.html

Szerkesztői megjegyzés: a tanulmány alapját képező dolgozat a XXXV. OTDK Tanulás- és Tanításmódszertani - Tudástechnológiai szekciójában a Fenntarthatóságra nevelés tagozatban II. díjat nyert el. 